\title{
Performing rituals of affliction: how a Governor's Press conferences provided mediatized sanctuary in Ohio
}

\author{
Celso M. Villegas ${ }^{1}$
}

Published online: 7 October 2020

(c) Springer Nature Limited 2020

\begin{abstract}
This paper studies the ritual and aesthetic performances of Ohio Gov. Mike DeWine's Coronavirus press conferences. It argues that the press conferences are mediatized sanctuaries-solidaristic respites from the chaos of pandemic and partisan politics. They achieve this via performing a regular ritual of affliction where basic cultural commitments are affirmed, institutional action is validated, and the where the trouble of Coronavirus can healed as a result.
\end{abstract}

Keywords Coronavirus · COVID-19 $\cdot$ Press conference $\cdot$ Ohio $\cdot$ Ritual $\cdot$ DeWine

In the absence of a coordinated federal response on Coronavirus, U.S. governors have taken the lead in implementing public health interventions for their states. Regular televised press conferences have been a central means by which governors have communicated these interventions to audiences statewide and nationwide. Historically, more and more media attention and symbolic power have accrued to the U.S. presidency (Mast 2013, pp. 25-42). So it is surprising that governors have drawn national and international attention for their efforts "in a fashion that sharply breaks from the Washington-centric lens through which government has been viewed in a period of national and celebrity-oriented politics" (Martin and Burns 2020).

On the one hand, governors as "official producers of information" have an array of technical, professional, and institutional resources to put on well-produced press conferences that can get the attention of mass media (Habermas 1996, pp. 376-377). As "public spheres organized for the benefit of the media," press conferences can meet Habermasian standards for ideal speech situations (Jacobs 1999, p. 359), and their dialogic and interrogative dynamics provide a context for the successful performance of politics (see esp. Craig 2016; cf. Alexander 2010). In this sense, we might say that governors like New York's Andrew Cuomo and the subject of this paper

Celso M. Villegas

villegasc@kenyon.edu

1 Department of Sociology, Kenyon College, 103 Ward Street, Gambier, OH 43022, USA

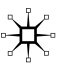


Ohio's Mike DeWine have achieved positive recognition and support for their interventions because of these several built-in structural advantages.

On the other hand, there is more than just structural advantage and speech situation operating here. Ostensibly vehicles for reporting on current data and public health interventions, governors' press conferences have additionally provided audiences with a feeling of comfort and stability. Given the high partisanship and political polarization in the U.S. (more on this below), such feelings of comfort seem out-of-place. In one notable piece, Jezebel's Rebecca Fishbein confesses to having "Stockholm Syndrome" induced by Andrew Cuomo's press conferences: "[W]hen I stream his presser on the governor's website-every day around 11:30 am, complete with PowerPoint presentation-I feel comforted. I feel alive. I feel protected. I feel... butterflies" (2020). After timidly declaring her "love" for the Governor, she knows she "will need an endless amount of anti-brainwash therapy so I can rightfully yell at him for using prison labor to make hand sanitizer" (Fishbein 2020). Fishbein presents herself as an otherwise rational, left-leaning critic of Cuomo, but is taken aback by her aesthetic reaction to his performances. So beyond the press conferences offering a context for the presentation of data and political action and their interrogation, there is a cultural horizon that must be taken into account-one that at least surrounds if not exceeds a Habermasian structure rooted in rational speech acts (see Alexander 1985, pp. 415-418; 2006, p. 16).

What kind of cultural structure are these press conferences and why do they have these aesthetic effects? This paper analyzes the Coronavirus press conferences given by Ohio's Republican Governor Mike DeWine from March 3 to June 11, 2020. It argues that Gov. DeWine's press conferences became mediatized sanctuaries-solidaristic respites from the chaos of partisanship in order to deal with the pandemic. They did so by performing a modern-day "ritual of affliction" (Turner 1981, 1985) in which responsible actors assure those gathered that their actions to stave off disease can be divined to have positive effects on the reintegration of society. This ritual structure was a contingent, performative achievement (Alexander 2011), which came about when precautions for the virus altered the staging, script, and interrogative dynamics of the press conferences, coupled with the virtuoso on-screen performances of Ohio Director of Health Dr. Amy Acton. The effect was that the press conferences exceeded their ostensible presentation for the media and became a regular ritual respite for audiences at home.

While this paper contends that the press conferences were at their core consensual and affirming events, audiences responded in multifaceted ways to the press conferences as a cultural structure (cf. Shils and Young 1953; Birnbaum 1955). First, public polling showed overwhelming support for DeWine and Acton's interventions to flatten the curve. Second, DeWine and Acton achieved iconic status as cultural performers. Reflected in different kinds of creative, aesthetic products-from Facebook fan pages, to YouTube videos, drinking games, and kitschy trinkets-audiences engaged with the likenesses of DeWine and Acton through an array of laudatory and even critically self-aware creations. Third, DeWine, Acton, and the press corps became direct targets of populist backlash (Alexander 2019) starting in early April, eventually leading to Dr. Acton's on-screen resignation on June 11. The backlash ended the press conference's performance of sanctuary and moved audiences 
towards what Turner called the "recognition of irremediable schism" (1985, p. 220). In short, these press conferences did more than simply convey case numbers and mandates: they provided a symbolic font from which audiences could spin their own webs of meanings - affirmative, self-aware, and contentious - in an otherwise unsettled and dangerous time.

A caveat: while this paper is interested in thick description of the case, it does not intend to fully catalog nor can it explain all policies, interventions, orders, etc. dealing with the spread of Coronavirus in Ohio. Instead, it treats policies and interventions as part of the webs of cultural performance the press conferences spun-the emphasis paid on the performance. In doing so, this paper hopes to explain how policies were made meaningful—solidaristic early on, and polarizing afterwards—and how the press conferences embedded those meanings in a shared cultural horizon.

\section{The coronavirus press conference: media event and performance}

U.S. governors' coronavirus press conferences have features of "media events": exceptional, solidaristic, broadcast-monopolizing interruptions in the media landscape, "high holidays of mass communication" that "remind societies of their commitments to established values, offices, and persons" (Dayan and Katz 1992, pp. 1, 147). Like FDR's fireside chats, these press conferences "dramatize core social values" using "the routines and practices of... culture industries"-in this case, print media, television, and internet (Ryfe 1999, p. 84). They also conform to Simon Cottle's definition of "mediatized rituals": "...exceptional and performative media phenomena that serve to sustain and/or mobilize collective sentiments and solidarities on the basis of symbolization and a subjunctive orientation to what should or ought to be" (2006, p. 415). To be sure, since Shils and Young's analysis of Queen Elizabeth II's coronation, scholars studying media events have debated the value of "ritual" as an anchor concept because it elides the ideological functions embedded in both government propaganda and the mass media (Shils and Young 1953; Birnbaum 1955; Couldry and Hepp 2013; cf. Habermas 1996, p. 377).

But just as these press conferences do not necessarily generate influence from their structural speech situation, it should be noted that such high ritual is a contingent and pragmatic achievement (Alexander 2011; Mast 2013). In these press conferences, governors-as-actors must cathect to scripts and background cultural codes. If they do, then audiences can interpret their performances as authentic, and thus "fuse" with them (Alexander 2011; Mast 2013, esp. p. 11). In complex societies however, the components of performance are "de-fused." Subject to autonomous and contingent pressures, actors may not execute scripts in believable ways, audiences may fracture across different media and among themselves, and scripts may not effectively pull from background representations. Ideally, performances must "re-fuse" background representations, scripts, actors, and audiences to achieve performative success and by extension political success.

Three additional components of performance also impact fusion/de-fusion/refusion. Corresponding to the roles of director and producer, the mise-en-scène and the means of symbolic production affect how a performance is executed in real time 
through props, broadcast equipment, and staging (Alexander 2014, pp. 16-18). The unequal distribution of ideological, economic, military, and political power-social power (Mann 1986) - “forms an external boundary" to performances and limits them (Alexander 2011, p. 32). However, because "challengers beat incumbents" through their performances, the effect of social power is contingent, not fully determinative (Mast 2013, p. 13). This insight on contingency and social power has been productive in explaining the dramatic twists and turns in American politics in an age of high mediatization and charismatic characters like Barack Obama and Donald Trump (e.g., Alexander 2010; Alexander and Jaworski 2014; Bogard and Sheinheit 2016; Mast 2019).

But it is that kind of dramatic politics that splits U.S. audiences into partisan epistemologies. Facts and truth are understood to be Democratic or Republican (Kidder 2018; Kreiss 2019; Norton 2019), undermining the possibilities for ideal Habermasian speech. If "citizen-audiences do not feel compelled to believe the truth of what they see or hear" in this partisan context (Alexander 2011, p. 103), then it makes sense that well-researched and prudent interventions like masks, social distancing, stay-at-home orders, and contact tracing can become deeply politicized. Citizen-audiences concerned about the Coronavirus may find it deeply distressing to navigate this "paralogical hellscape" (Mast 2019, p. 262) on top of the disruptions of daily life and lives lost.

\section{Sanctuary in the age of social distancing}

Given that polarized context, this paper proposes that governors' press conferences fall into a new class of mediatized ritual. Media events and cultural performances have small-c conservative effects because they rely on existing codes, symbols, and narratives (see Binder 2017; cf. Ryfe 1999, p. 83). In this sense, the press conferences share a family resemblance with Cottle's "celebratory media events" (2006, p. 418) in that they are consensual and affirming in their cultural content (cf. Shils and Young 1953). But these press conferences are less celebratory rituals than "rituals of affliction" (Turner 1981, 1985). In societies faced with disasters, sickness, or widespread death, rituals of affliction recall basic cultural and social relationships and activate institutionalized mechanisms in order to respond to collective trauma:

Trouble, which may be man-made or a result of what we would call a 'natural disaster', may lead to a state of social relations in which feelings of anxiety, fear, and aggression become pervasive. Sentiments of mutual dependence are sooner or later mobilized by responsible persons; since the scale of action is public, this mobilization takes institutional forms, including recourse to divination to seek a ritual remedy. (Turner 1981, p. 52)

In rituals of affliction, there is a strong element of reflexivity, for through confession, invocation, symbolic reenactment and other means, the group bends back upon itself, so to speak, not merely cognitively, but with the ardor of its whole being, in order not simply to remember but also to remember its basic 
relationships and moral imperatives, which have been dismembered by internal conflict. (Turner 1985, p. 233, emphasis added)

For Turner, the social reflexivity of rituals of affliction "revive feelings of an underlying bedrock communitas" (1985, p. 233). These rituals can also be "prophylactic" to try to prevent future affliction as well (Turner 1985, p. 235). If we take Coronavirus as a kind of trouble that generates negative emotions, then institutional actors like governors fit Turner's definition of "responsible persons" who can generate institutionally supported public action. The upshot here is that such action is given meaning via carrying out a ritual of affliction.

In addition, governors' press conferences as rituals of affliction offer "an antitemporal stretch of ritual time" that "opposes and ameliorates the divided, all too temporal world of institutionalized social structure, if polity and economy are to work, but sensed also as the forked root of all social sunderings" (Turner 1985, p. 233). That is to say, they operate with an understanding of underlying social tensions that will undermine ritual remedies. The "divination" of disease modeling is dependent on human social behavior; flattening the curve requires collective action. If institutionalized life is to continue during and past the pandemic, then ritual action is needed to bracket out partisan epistemology and cross-cutting social powers for the time being. By recalling the most basic cultural commitments during press conferences, participants presume the damage caused by the trouble of the pandemic can be prevented or even healed.

Two additional features must be taken into account since these rituals occur in mediatized form. First, in several states press conferences have been regular occurrences in the media landscape-11:30 am in New York, 2 pm in Ohio, and so on. They are less interruptions in routine as they are or have become routine. Still, they retain a high attractive quality, this paper contends, because of their ritual aspects. Second, if media events work within existing culture industries, we should expect to see governors and their press conferences finding additional engagement through social media (retweets, blog post comments, Facebook groups, etc.) and through rebroadcasts on platforms like YouTube. In this sense, as citizen-audiences engage with the press conferences in a manner of their choosing, they open up the possibilities of iconic bricolage (Alexander 2008). This means they can purposefully take aesthetic bits and pieces from press conferences to build small mediatized sanctuaries of their own and share them with others. Through their aesthetic and creative reproductions, citizen-audiences spin thicker webs of significance beyond the original broadcasts themselves. This certainly can reinforce the small-c conservative qualities of mediatized sanctuaries, but like iconic photographs reproduced as kitsch these practices also can generate a critical public (see Hariman and Lucaites 2007, pp. 37-48).

Using Cottle's typology of mediatized rituals (2006, p. 426), this paper proposes that governors' press conferences are mediatized sanctuaries: performative media phenomena in which audiences and institutional actors respond to troubles by regularly carving out sacred time to recall basic cultural commitments in the face of societal conflict. They are less event-driven than they are story-driven, insofar as they situate current action in the context of future healing. They are 
consensual insofar as they recall base cultural commitments and they are affirming insofar as they are focused around established institutional actors. Mediatized sanctuaries fit strong definitions of mediatization (e.g., Couldry and Hepp 2013) insofar as the media form of institutionalized press conferences drives the enactment of the ritual itself. Given the context of a public separated physically by social distancing and stay-at-home orders, the sense of collectivity generated among participants occurs as a result of participating in rites with institutional figures on TV and on the internet.

To clear, the sanctuary of press conferences is fragile because it is contingent on the very things it hopes to exclude and address. U.S. governorships are partisan elected positions meaning they will be vulnerable to politicization by definition. Furthermore, as Jeffrey Alexander (2019) has argued, populist backlash in the U.S. has taken aim at the institutional foundations of the civil sphere-the sanctity of elected office and the media most notably, two key components of these press conferences. The Coronavirus spares neither Republicans nor Democrats nor does the virus take an 11:30 am break to watch the Governor speakactors will have to adapt as they try to maintain theirs and their viewers' safety. Still, the upshot of looking at press conferences as mediatized sanctuaries is that we can examine (1) how and to what degree they generate sanctuary and (2) what kind of performative contingencies might make it more or less likely for them to do that. This means we can look closely at actors, audiences, scripts, props and broadcast equipment, the mise-en-scène, and social power as they impact these outcomes.

\section{Methods}

Like many Ohioans I made it a point to watch the press conferences live at $2 \mathrm{pm}$ every day. If not, I watched recordings provided online by the state government's broadcasting service, The Ohio Channel. Like many academics, I also began to teach remotely in mid-March. As luck would have it, I was teaching a course on cultural sociology and was starting a unit with Jason Mast's The Performative Presidency (2012) as the anchor text. So in writing lectures and helping my students process events in their home states, I used Ohio's press conferences as a reference point, moving back and forth between my observations, my students' observations, and Mast's book. I continued this abductive media ethnography (Tavory and Timmermans 2014) as the school year ended. It is also fair to say that as a resident of Ohio and directly affected by the state's mitigation efforts, I was a participant-observer.

To shore up my observations for this paper, I re-watched 64 press conferences from March 3 to June 11, taking notes on the six components of cultural performance-background representations/scripts, actors, audiences, mise-en-scène, the means of symbolic production, and social power. I supplemented these notes with articles published by local, national, and international news media about the press conferences themselves to get at wider interpretations. My focus in the rest of the paper will be attempting a thick description of these press conferences and 
the press conference's reception. I will highlight points of successful performative fusion and suggest that they are linked to Ohio's early efforts to manage the pandemic.

Do we get much more purchase by looking at Ohio specifically? Ohio is less a battleground state than it is a bellwether one, meaning it reflects broader trends favoring the winner of presidential elections (Hendriks and van Doorn 2015). While Democratic presidential winners have only lost Ohio twice, "no Republican has ever reached the White House without carrying the Buckeye State" (Coffey, Green, Cohen, and Brooks 2011, p. 17). Ohio had gone for Obama in 2008 by 4.5 percentage points and 2012 by 3 points, but the state broke for Trump in 2016 by 8 points. In the 2018 midterm elections in which the Democrats gained control of the U.S. House of Representatives, Ohio Democrats lost 6 out of 9 statewide races, with only incumbent Democrat Sherrod Brown winning re-election to the U.S. Senate and two candidates for Ohio Supreme Court who were listed as nonpartisan on the ballot. In the 2018 gubernatorial election, Republican Mike DeWine, a four-decade veteran of Ohio electoral politics, beat his Democratic challenger Richard Cordray, $50.4 \%$ to $46.7 \%$.

On top of that, Ohio is gerrymandered in favor of Republicans: "In Ohio House races [in 2018], Republicans got $52 \%$ of the vote but won $61 \%$ of the districts, allowing them to continue to hold a super-majority despite losing five seats" (Wehrmann and Siegel 2019). That Republican supermajority quickly passed a controversial fetal heartbeat abortion bill, which Gov. DeWine signed in April of 2019. Thus, polarized partisan epistemologies and political institutions overlap in Ohio. In this sense, Trump's win in 2016 is not surprising and Ohio's continuing partisanship is not surprising either. If Ohio is a bellwether, then it portends a very strong rightward American polity in general.

But contingency in performance attunes the researcher towards surprises. So it was surprising given Ohio's strong partisanship in the Trump era that DeWine took early action to mitigate Ohio's exposure to Coronavirus. On March 3, he forbade spectators at the Arnold Classic - a bodybuilding and fitness exposition with an estimated 250,000 attendees - and was the first in the country to close K-12 schools on March 12. A slow economic shutdown took place from the March 12 to March 18 when Dr. Acton signed a stay-at-home order. These early and metered actions earned DeWine plaudits from The Washington Post on March 16 (Witte and Zezima 2020), The New York Times on March 17 (Martin and Burns 2020), and the BBC on April 1 (BBC 2020). Indeed, the Times was surprised at DeWine's growing celebrity status: "For example, it would have been difficult to picture Mr. DeWine, a mild-mannered government lifer first elected county prosecutor in 1976 a daytime sensation. But there he was on ABC's 'The View' on Tuesday morning, appearing via satellite from Columbus" (Martin and Burns 2020). The rest of this paper will try to explain this surprise. 


\section{Breach and crisis: the ritual of affliction takes shape}

On March 9, DeWine announced that Ohio had its first three cases of Coronavirus. With the primary elections coming up on March 17 (which would eventually be postponed), DeWine encouraged early voting and announced policy and cost reduction changes for government offices. He also declared a State of Emergency enabling procurement of medical supplies without the regular bidding process, though later in response to a reporter's question he notes, "Let me be candid: I would not read too much into the State of Emergency... I think listening to what Dr. [Amy] Acton says is more important than hyping the State of Emergency" (Ohio Channel 2020b, 16:14-16:42). Worth noting, Lt. Gov. Jon Husted makes his first appearance, but his role is very much undefined. He stands in the background for nearly half an hour until a reporter asks a question about elections he can contribute to-a question on elections as Husted was formerly Secretary of State.

In Victor Turner's terms, DeWine and Acton acknowledge the "breach" of Coronavirus and the attendant "crisis" to follow. DeWine offers an observation on March 9:

There are lessons we can learn from previous pandemics and crises like this. I'm actually reading a book now [John Barry's The Great Influenza (2004)] on the Influenza of 1918 and they make a distinction... how two cities handled it. St. Louis handled it well, Philadelphia did not. A lot of it had to do with just the openness and candor of officials. (Ohio Channel 2020b, 05:26-05:56)

Later in the press conference, Dr. Acton also remarks on the exceptional and historical quality of the moment: "This is a once-in-a-fifty year situation and we're seeing... sort of the psyche of the whole country wake up to this, moment-by-moment" (Ohio Channel 2020b, 25:40-25:49). In Turner's terms, the "regular norm-governed social relations" were now breached and as the virus could spread to different institutional contexts, the liminal phase of crisis required extraordinary action (1985, p. 121). DeWine sets the terms for how the press conferences and his actions will affect Ohioans:

... as this situation is analyzed, we're gonna be... you're gonna be getting announcements from us every single day. Look, we have to be cautious: this will change people's lives for a while and the whole goal is to make sure Ohioans are safe and so we have to focus on that at this point. (Ohio Channel 2020b, 15:42-16:03)

On March 10, DeWine says, "We are now at a critical time here in Ohio in regard to the Coronavirus. Decisions we make as individuals in the next few days, in the next several weeks, will determine how many lives will be lost in Ohio..." (Ohio Channel 2020c, 00:00-00:23). He says, "Every action each of takes can-can-and will help saves lives" (Ohio Channel 2020c, 01:26-01:31). DeWine walks over to what will become a familiar prop-a large poster board dominated by two curves, a yellow one with a steep and high peak, overlaid with a flatter light blue one. This image comes with an exhortation from Dr. Acton to "flatten the curve." Referring back to 
John Berry's The Great Influenza, DeWine and Acton again exhort Ohioans to be more like St. Louis-which mitigated the spread of the flu-rather than Philadelphia-which did not.

With these historical lessons in hand, the governing team understands this to be a critical juncture-resolute and immediate action now will change the state's path and that regular life as we know it will need to fundamentally interrupted. "We have to stop what we are doing, we have to lead by example" DeWine says about his and Husted's giving up on hand-shaking and statewide travel on March 11 (Ohio Channel 2020d, 19:05-19:09). On March 12, DeWine announced that Ohio would be closing all K-12 schools. In a long response to a reporter's question about free school meals being affected as schools close, Dr. Acton directs her answer to viewers at home and says "Please know that lots of rules are going to be broken; our country will be fixing it backwards... (Ohio Channel 2020e, 44:00-44:11). Gov. DeWine interrupts, "Look, the government and the citizens of Ohio, we have to have the attitude that this is a crisis and we have to do what it takes to get the job done..." (Ohio Channel 2020e, 44:25-44:33, emphasis added). Within just a few days, Ohio's governing team moved the ritual process forward from breach to crisis. To ameliorate these breaks in complex institutional life, the next phase of ritual would need to recall basic cultural commitments.

\section{Sanctuary Mise-en-scène}

To attempt to redress the breach of Coronavirus and the crises spreading out across institutional contexts as a result, the governing team happened on a ritual performance reliant on several contingent circumstances. The following is a composite, thick description of the daily ritual of affliction carried out during the press conferences from roughly March 17 to April 17.

The camera opens on the State Room in the Ohio Statehouse. More often than not, the camera work starts with a slow zoom onto DeWine. On some days, we can see Husted, Acton, and DeWine solemnly process in, each taking their positions on the stage. DeWine stands behind a podium with the Seal of Ohio on the front, a long microphone extends from a corner of the podium. The microphone is sharply bent to accommodate his height. Next to the podium on one side is a small table where DeWine sets down the props he will use for the day. On the other side is a smaller table with a well-used bottle of Purell (we never see DeWine use that bottle, though). Directly behind him are the American and Ohio flags, and behind to his right is a flatscreen TV with the Ohio Department of Health's COVID hotline-833-4-ASK-ODH. In a picture-in-picture inset in the upper right-hand corner of the viewer's screen, we see sign language interpreter Marla Berkowitz. "Afternoon everyone," DeWine says with folksy cheer. Berkowitz smiles and signs "Good afternoon," adding quick waves with her fingers to "afternoon" like she is greeting friends.

To start the day's ritual of affliction, DeWine leads an affirmation of basic cultural commitments and the continuing function of basic institutions. Family and children are the most consistent theme. DeWine's wife Fran appears from time to 
time in this slot. On March 25 and April 10, Fran shows off homemade masks, shares some arts and crafts ideas for kids and some simple recipes. On April 1, DeWine narrates a photomontage of a family finalizing the adoption of their son, James. On April 2, DeWine introduces a video skit by Junior Girl Scout Troop \#71268 who explain they will be collecting donations to give Girl Scout Cookies to truckers at rest stops to help those who keep the supply chain going. "Very cute. A good thing to do. A good deed," DeWine chuckles approvingly (Ohio Channel 20201, 2:31-2:36).

Compared to the imminent threat of the pandemic conveyed in his introductions during the early March press conferences, DeWine acts out a new script. He cathects to it in a natural way. He gets to be homespun and grandfatherly-and he seems to enjoy this additional characterization to his serious leadership. His costume changes too. Instead of monochromatic ties, he begins to wear ties representing baseball teams in the state, and then ties representing different Ohio colleges and universities. He does not say anything about this change at first-it is Dr. Acton who brings it to the audience's attention on April 3: "I'm wearing a bit of bling today for Youngstown State, my alma mater... The Governor is wearing a Youngstown State tie as well" (Ohio Channel 2020m, 30:15-30:26). On April 4, DeWine felt compelled to start the press briefing "on a lighter note" by going into painstaking detail about his choice of ties:

Happy Saturday everybody... I've been receiving some questions about the different ties I'm wearing, and I'm not a person who usually get too many question about my clothes [someone laughs in the room]. But I thought I would share the story about these ties. With the exception of three days that we devoted on the ties to baseball on what should have been Opening Day and the blue tie I wore several days ago in regard to Autism Day, what I've been trying to do is wear a tie each day from a separate college or university in Ohio. And one of the great assets that we have is that we're truly blessed with some amazing colleges and universities.

And I started off with my two alma maters, Miami University and Ohio Northern and I've also worn Bowling Green. Many of these schools have different meanings, you know, in our family, we've got a large family. Bowling Green tie: my cousin Nick works [sic] at Bowling Green for many, many, many years. The College of Wooster where our grandson Albert went, our son Mark, and our late daughter Becky went to the College of Wooster. Ohio State: we have a number of family members who went to Ohio State. Granddaughter Izzy got her undergraduate degree there, and our son Brian got a Master's degree, and our son-in-law Bill got his Ph.D. there. Youngstown State: from my good friend Jim Tressel, [I] wore that tie yesterday. Of course that's Amy's [Dr. Acton's] alma mater as well. University of Dayton, Ohio University where my sister-in-law and her husband Chris went to school... [let's] see who else I have missed down here... [he checks his notes]. And today is NEO Med, Northeast Ohio Medical University, another one of Amy's alma maters. [To Dr. Acton] You brought a scarf from there, I believe, so you can show them that. Anyway, to start on a happy note... (Ohio Channel 2020n, 0:05-2:29) 
About a week later on April 10, DeWine calls this “...our tradition of honoring Ohio universities..." (Ohio Channel 2020q, 0:13-0:15, emphasis added). With few exceptions in my sample, DeWine conducts the tie ritual at every press conference. He acknowledges any number of friends, relatives, friend's relatives, staffers, members of the press, or notable Ohioans who attended those schools. As the long excerpt shows, the tie ritual does not just reaffirm the university as key institution in the social system, but it is also a vehicle for DeWine to affirm just how colleges and universities meaningfully fit within a larger system of personal and family relations. Now physically manifest on the body of DeWine the actor, the audience is reminded of the meaning of "family ties" as they pertain to the institutional figure leading the affliction rite.

The main reports begin. DeWine starts. His remit is the broadest of the three actors on stage as he introduces new initiatives; reports on infrastructure and testing; the work of the Ohio National Guard; and his conference calls with the President, Vice-President, and other governors-essentially the big picture. If needed, he invokes the ritual act of signing executive orders or health orders, the latter of which according to the Ohio Constitution must be done by the Health Director. He reminds the audience that the work they have done by staying at home, social distancing, sanitizing at stores, and wearing masks has flattened the curve.

We are no longer "at war with an enemy" as DeWine narrated it in early March. First responders, hospital staff, and local health departments still make up the "front line," but Coronavirus changes from an "enemy" or "invader" to "an invisible monster" as time goes on. And because Ohioans have been sacrificing parts of their daily lives, the "invisible monster" is being placated with these sacrifices - and by responsible parties responding in kind (Turner 1985, pp. 219-220). For example, on April 6 , DeWine tells us, "Big picture of course is that what you are doing every single day is buying us time... you're buying our hospitals time... Our goal is to double the capacity, the number of hospital beds... as well as a number of other things we have so that hospitals can accommodate up to... doubling the amount of people who may be coming in (Ohio Channel 2020o, 4:28-5:02). Again, addressing the affliction gives all these actions meaning: the healers' work against the trouble needs sacrifices to continue - every single day — and correspondingly institutional actors will work-every single day - to ensure the healers can act and the community's sacrifices are not in vain.

Husted or Acton comes next. Let us follow the camera to Lt. Gov. Husted. He is stage left, sanding above a long desk with a piano behind him. A former college football player, Husted is broad-shouldered and tall, sometimes his suit seems too big. He speaks calmly. He is deferent to Gov. DeWine and Dr. Acton. He gives off feelings of patience and duty. He too is a family man and in a reflexive way, notes how the press conferences help him reaffirm basic cultural commitment to the family unit:

Right now, my daughters are at home, they get their science lesson from Amy [Acton] at these two o'clock briefings when they're doing homeschooling. They do the home ec portion of it that Fran [DeWine] talked about with cooking... I know I talked to my wife last night and she was talking about what a 
gift this is - an unexpected gift that they're getting to bond and grow closer together as moms and daughters and I hope that's happening for your family in these very difficult times. (Ohio Channel 2020g, 23:46-24:15)

His portfolio includes businesses and unemployment, putting him at the border between the state and the economic sphere. Ohio's unemployment rate for March 2020 was 5.5\% with 39,700 jobs lost, in April it rose to $16.8 \%$ with 823,700 jobs lost (Exner 2020a, b). Husted has the challenging task to manage the unemployment system and its front-end website, which always seemed to be crashing. Businesses have been calling local police about the Dr. Acton's orders-are they "essential businesses" or not?

Husted colors his remarks with themes of responsibility and the obligations of office. "One of the things we try to do here every day is respond to the questions that you have. I can tell you that the three of us and our entire team feel so responsible to you," Husted says at the beginning of his presentation on March 26. "When we're going through this difficult time, we want to make sure that everything we can do on our end to ease the burden in your lives is a top priority for us" (Ohio Channel 2020h, 24:30-24:45). He feels "obligated to address" issues with the unemployment system he tells us on April 8. "We are not doing this in isolation," he says on the State's plans to reopen businesses. "We are asking people who know, who are experts, who are professionals at this, you know, "what is it that we need to do to help?"' (Ohio Channel 2020p, 28:52-29:03). In doing so, he assures us that the ongoing affliction ritual will lead to material benefits too (see Turner 1981, p. 52).

The camera pans to Dr. Acton. She is wearing her iconic outfit: a white lab coat with her name printed on a front pocket and the logo for the Department of Health on the other side. Her long brown hair drapes over her shoulders, her glasses hang from her shirt collar. Her presentations review the new data on cases and deaths, but she also details efforts coordinating with hospitals, hospital systems, and local health departments. She is the first person with a medical degree to run the Ohio Department of Health. She gives empathetic reassurances and candid, detailed explanations. She reads notes from long rectangular cards while a large flatscreen TV flashes slides with the day's new data. Though her star has risen quickly, she remains very deferent-she situates her humility inside of existing institutional norms and roles in the government. She says on March 25 before responding to a nine-year old's letter to her:

I want you to know a couple things. First of all, sometimes I feel that I don't really deserve all this attention I'm getting. I am one person in a point in time, and there was a lot of serendipity that brought me to the good fortune of working for the most amazing Governor, and First Lady, and the Lieutenant Governor... But just like our data, I'm the tip of the iceberg. I am a tip of the iceberg of some amazing colleagues of mine, cabinet members, and really, public servants. It is our job to do this for you. (Ohio Channel 2020g, 20:53-21:35)

Evoking the function of the ritual of affliction she continues, "I think the First Lady really eloquently said it. You know this is going to be a time that we look back on, and it's forcing us to slow down and see things in a different way, to observe 
differently" (Ohio Channel 2020g, 22:16-22:30). She too speaks to children: she asks them to "don their capes," she tells them that she is not fearful but rather determined. They write to her and draw pictures of her in her lab coat.

But her specific ritual role here is of the diviner. Insofar as disease modeling and epidemiology are important sciences for public health interventions, we can read Dr. Acton's reports as strictly scientific ones. But, these mid-March and early April press conferences have to work with more incomplete information than we have now. We do not know the effect of the seasons on the spread of the virus, among a whole host of other factors, she notes. The State's COVID-19 Dashboard becomes more elaborate over these few weeks and she invites us to read the same data that come to the State. Indeed, they make the data available in raw form as a .csv file, allowing others to develop their own charts and tables.

But more than presenting just raw data, Acton performs a kind of ritual augury to make the data meaningful. She calls her data analytics team "The Force"-a reference to Star Wars and the metaphysical energy that suffuses that universe. In order for the good scenario divined to occur-a flattened curve-not only do people have to recall their basic commitments and make sacrifices, social conflicts have to be set aside. "First of all, there is a lot of blaming and finger pointing," Acton points out, echoing Turner in the kind of reflective exercise that trouble induces in societies (Turner 1985, p. 233). "It is really important to understand that there are complex reasons, far beyond any one president or any one person that has led to what is almost a perfect storm of this enemy we're facing with this virus..."

You have to learn quickly and you have to be able to take in a ton of scientific information, a ton of advice, and make some really hard decisions. But the ability to do that and not have a bias - we all have biases. We all have biases based on the way we've interacted with the world prior to the day we're in [sic]. And it's really hard to set those aside and set yourself up to such rapidfire information and then be able to pluck the best things.... (Ohio Channel 2020j: 41:37-42:17)

Here divination and the institutional response it can inform cannot be done without acknowledging the effect of conflict in our own minds. In that sense, she reinforces the affliction ritual's theme and asks that its sanctity be maintained so healing can take place under the auspices of institutionalized authority.

So in each of the main cast's work we can detect the three key components of a ritual of affliction. DeWine, Action, and Husted all remind the audience about their basic cultural commitments to family and children. All three reinforce the institutional solution to the trouble of coronavirus. All three make careful moves to keep partisan epistemology out of the ongoing ritual. And in moves that situate actions taken to slow the spread of the disease and manage hospital capacity in meaningful ways, the three principal cast describe a currently ineffable force which can be tamed by institutional power if collective sacrifices can be extracted from the people. 


\section{Democratizing the ritual, ritualizing democracy: the question-and-answer period}

A calm pause and the camera pans back to DeWine. "Time for questions," DeWine announces. On April 1, DeWine describes the scene to viewers to remind them of the changes made for the sake of social distancing:

As they're coming up, I want to kind of describe this scene again. You all cannot see it out there on TV. But the reporters are spread out in a big room in the Atrium of the Capitol building, and they are observing great social distancing between each other. And we're gonna start with Mr. Otte from WHIO, Channel 7 in Dayton. How's that, Jim? (Ohio Channel 2020k, 35:51-36:19)

The tensions audiences might have seen between the national and international press and President Trump seem so backwards compared to this cooperative and congenial tone (see, e.g., Sopel 2020). It is worth noting here that DeWine and Husted, both Republicans, emphasize their good relations with President Trump and Vice-President Pence. "Let me just say that I think the President and I are aligned," DeWine says on March 24. "The frustration he has-I share that frustration... We want to get people back to work... So we're all in this together, and really we have the same feelings about this" (Ohio Channel 2020f, 13:55-14:28). This is a repeated refrain from DeWine and Husted as a part of the ritual of affliction: We don't actually disagree with the President.

So too the relations between the reporters seem more orderly. ${ }^{1}$ In early March, reporters sat in tightly ordered rows of chairs facing DeWine, Acton, and what seemed to be a rotating cast of characters on stage at in the Harding Press Room in the Statehouse and then in the larger Finan Hearing Room. The question-andanswer period during these press briefings was more of a free-for-all: reporters jockeyed for DeWine's or Acton's attention, interrupting those on stage or even interrupting or shouting louder than each other to try to get a word in edgewise. DeWine wasted no time in answering a reporter oftentimes in a curt way, interrupting them or calling on another reporter to signal the end of his answer.

However, the US Centers for Disease Control (CDC) gave guidance in midMarch that no more than ten should be in a room. So the press corps moved on March 17 to the Ohio Legislative Correspondents' Association (OLCA) Room while the main cast moved to the State Room. A closed-circuit TV feed linked the two rooms together. While the move met CDC regulations for the press conference site itself, the OCLA Room was too small for the press corps and their support staff. So on March 23, the press corps moved to the Statehouse Atrium, a much larger room where they could much more easily social distance. To help manage social distancing and the shared microphones, Dan Tierney, DeWine's Press Secretary, proposed a system where reporters would put their names in a hat about fifteen or so minutes before the briefing and then by random drawing, be placed in a queue for asking questions for the day's press conference. If time

\footnotetext{
1 Many, many thanks to Andrew Welsh-Huggins for providing key details about the press corps at the Statehouse.
} 
ran out before a reporter could come up to the mic, then they would go to the top of the list for the following press conference. Each reporter was limited to one question (one question per outlet, technically), and multiple questions and followups were discouraged.

The cumulative effect of these changes altered the dynamics between the press and DeWine. Whereas in the early March press conferences six or seven reporters were able to ask questions by jockeying for attention and interrupting those on stage, the new system ordering the reporters by lots gave at times twelve to fourteen reporters from different media outlets opportunity to speak.

These changes also precipitated a ritualized, mimetic script as the reporters would address the microphone for their question: each reporter would greet the governor, introduce themselves and their news outlet, and state to whom their question was directed. "Hello Governor. This is Laura Hancock with Cleveland.com. This question is for you and Dr. Acton... Hello Governor, Luis Gil with OhioLatino TV... Good afternoon. I'm Ben Schwartz from WCPO in Cincinnati. I have a question for Dr. Acton... Adrienne Robbins, NBC4. Governor..." Now off-screen but audible, reporters quite literally become household names. And certainly there are questions that need to be asked and government needs to be held to account: how are we testing in nursing homes? What is the plan for child care if the state is to reopen? Why will you release some inmates and not others? The unemployment website is crashing, who should readers call? Is your model still accurate? In terms of the ritual of affliction, how will institutional life continue? How will healing take place?

Each of the main cast have readable features when they respond. Neither DeWine, Acton, nor Husted interrupts the reporter. The camera trains on DeWine as he listens. He cocks his head as if to hear more clearly, he nods and purses his lips as if to show he understands the point of question. If the question is for Dr. Acton, the reporter waits as camera pans to her. Dr. Acton nods as she listens, her face showing thoughtful concern as she looks into the camera, her fingers interlaced in front of her-for now, as she will talk animatedly with her hands when she responds. "I can follow up on that," Lt. Gov. Husted says. The camera briskly pans over to stage left. Husted looks into the camera and adds his contribution. "Thank you," the reporter says. Husted nods and mouths a silent "you're welcome" or "yup."

As all this is happening, in the upper right-hand corner of the screen sign language interpreter Lena Smith steps into view and removes her mask. She signs for the reporter. When DeWine, Acton, or Husted responds, Marla Berkowitz takes Lena Smith's place. This process is repeated for each reporter's question. The hearing viewer might glance at Berkowitz's animated signing. With her blue blazer, gray hair, and blue-rimmed glasses, the viewer might revisit a thought a friend shared with them on social media: "She does look a little bit like DeWine."

As a function of the means of symbolic production and staging, the main cast looks directly into the camera as they speak. In contrast to the majority of the press conferences prior to March 17 where a two-camera setup captured wide shots of all of the cast on stage and the reporters in the audience, now a single camera does all the work. While ostensibly DeWine, Acton, and Husted are speaking to the reporter via simulcast to the Atrium, because of the single-camera setup, the home audience sees each of the governing team talking to them straight on. And so as the main 
cast responds to Jim Otte or Laura Bischoff or any of the other reporters remotely, the closely cropped, single-camera shot effectively breaks the fourth wall: the home viewer becomes the direct addressee. The team may acknowledge they're speaking to Jim or that "they will look that up for you," but since the effect is that they are speaking to the home viewer, they will look up that statistic, that rule, or that report for you. So by dint of this feature of production, the press corps facilitate a mediatized relationship between audience and leadership. That relationship is deferential, in keeping with the ritual of affliction, but also reasonably critical in keeping with the function of the press in the civil sphere (Alexander et al. 2016). In this way, the press conferences contain the dialogic and interrogative qualities of the Habermasian ideal type, but situate and structure those interactions in a ritualized way and extend their public performance.

The last reporter for the day introduces themselves then announces theirs will be the final question for the press conference, "I've been told that I have the last question." The reporter asks their question and receives their answer. DeWine then introduces the day's recessional hymn - a video of a college marching band playing their school fight song, an encouraging new public service announcement featuring local notables, a video or picture montage of regular Ohioans doing their part set to inspiring music. DeWine makes a three-quarter turn away from the camera towards the TV screen behind him playing the video. Perhaps the camera takes a tight shot at the TV screen, but more often than not we can still see the Governor, paying rapt attention or bouncing along with the music. And like the Mass, one really should not leave before the priest himself processes out of the church. Once the song is done, the camera pulls back and with a smile DeWine turns back to us with a folksy "That's really great." "We will see you all tomorrow at two o'clock," he says. "Thanks a lot."

\section{Reception I: polling and public aesthetics}

What I described above seems like high ritual. Indeed, one might get the impression that Ohioans who watched the press conferences were enraptured in an irrational deference to a big-C Conservative governor or a Democrat infiltrator posing as a health director-depending on your partisan epistemology. As Cottle insists, however, mediatized rituals generate a self-aware public not a mass (2006, pp. 415-417), and we should be sensitive to explaining the reception of rituals as Norman Birnbaum insisted years ago (1955). This section will cover two "measures" of reception-polling and aesthetics-and will show (1) the quite thorough public support for DeWine, Acton, and their handling of the pandemic; and (2) the varied array of aesthetic reactions and engagements, anchored by the iconic qualities of the press conferences.

Simply put, public polling showed overwhelming support for DeWine's handling of the pandemic. In a Washington Post-IPSOS poll conducted April 27 to May 4, 2020, DeWine's approval was the best in the nation among governors: "In Ohio, $86 \%$ of adults [336 respondents] say they approve of the way Gov. Mike DeWine (R)... has dealt with the crisis" with $14 \%$ disapproving (Clement and Balz 2020). The 
closest governor to DeWine was New York's Andrew Cuomo with 81\% approval; both governors were well above the average approval rating of 71\%. FiveThirtyEight estimated that DeWine's poll numbers rose 31 points from his approval rating prepandemic (Mehta 2020). In June, partisan support for DeWine had become slightly more marked with more approval from Democrats (81\%) than Republicans (76\%) (Bischoff 2020).

Baldwin Wallace University's poll of 872 self-identified registered voters in Ohio conducted between April 20 and April 25 gives more insight into DeWine and Acton's support. Overall, DeWine's favorability was at $75.1 \%$, with $74.4 \%$ of Democrats, $78.4 \%$ of Republicans, and $71.3 \%$ of independents registering favorable support (Baldwin Wallace University 2020, p. 8). ${ }^{2}$ On COVID-19 in particular, $55.7 \%$ of respondents strongly approved and $29.3 \%$ somewhat approved of DeWine's handling of the situation, with $79.2 \%$ responding that he had acted at the appropriate time (Baldwin Wallace University 2020, p. 17). Compared to President Trump, $45.1 \%$ of respondents said DeWine was doing a much better job, $29.9 \%$ said he was doing a somewhat better job, and $55.7 \%$ of respondents chose DeWine over Trump when asked whom they trusted more to provide information about COVID19 (Baldwin Wallace University 2020, p. 18). Dr. Acton had a 63.7\% overall favorability rating, with slightly more Republicans (65\%) favoring her than Democrats (63.6\%) (Baldwin Wallace University 2020, p. 8). In addition, 55.3\% of respondents said they trusted Dr. Acton a great deal to provide accurate information on COVID19, with $28.4 \%$ saying they trusted her a fair amount. DeWine and Acton's bipartisan support here is exceptional not only given the context of the pandemic, but also given Ohio's partisan political landscape.

In addition, the Baldwin Wallace poll numbers also show overwhelming support for the Governor's interventions. 66.3\% strongly supported DeWine's stayat-home order, with $73 \%$ of Democrats, $63.5 \%$ of Republicans, and $60.3 \%$ of independents registering strong support (Baldwin Wallace University 2020, p. 20). $65.2 \%$ of respondents strongly agreed with DeWine's decision to close K-12 schools, with 20.7\% somewhat agreeing (Baldwin Wallace University 2020, p. 21). By contrast, $49.3 \%$ of respondents strongly disapproved and $15.6 \%$ somewhat disapproved of Pres. Trump's call to protest stay-at-home orders (Baldwin Wallace University 2020, p. 33). Finally, $75 \%$ of respondents thought that COVID-19 was a real threat compared to $17.1 \%$ who thought it was blown out of proportion (Baldwin Wallace University 2020, p. 45). All in all, these poll numbers serve as reasonable proxy measures for how the press conferences were received.

However, polling is only part of the picture of what constitutes the audience's fusion with the action on screen. Closures, social distancing restrictions, and stay-at-home orders gradually put Ohioans out of physical touch with each other, but in virtual touch via their shared viewing of the Governor's press conferences. It is this visual dimension that requires attention here: DeWine, Acton, and the press conferences themselves are icons. They have an aesthetic surface that

\footnotetext{
${ }^{2}$ Lt. Gov. Husted received a plurality of unsure responses at $47.9 \%$ (Baldwin Wallace University 2020 , p. 9).
} 
conveys moral depth (Alexander 2008). Furthermore, their iconicized aesthetic representations not only show evidence of fusion but also of the public's critical self-awareness.

Acton's iconic power rose quickly after her early press conferences appearances in March. Her performances conveyed intelligence and empathy in audiovisual form. So audiences took on her iconic look and iconic script, and in turn the state government used that to amplify its message. During the March 30 press conference, DeWine debuted a video tribute to Dr. Acton made up from videos posted on the Dr. Amy Acton Fan Club Facebook group. Acknowledging Acton's surface/depth linkage, the video begins with a clip of Acton asking the audience to "don your cape and keep being a force for good" (Ohio Channel 2020a, 0:00-0:08). It then shows a young girl wearing a white lab coat and adult-sized shoes, clomping towards a table with a cardboard image of the Ohio Seal on the front. She takes her place behind this makeshift podium and says, "Hi I'm Dr. Amy Acton. Any questions?" (Ohio Channel 2020a, 0:08-0:11). This is followed by photos and videos of young children wearing lab coats, capes, holding inspiring signs, and mimicking Dr. Acton's press conference encouragements: a bricolage made out of iconic bricolage. The video associates Acton with the heroism of superhero capes, her lab coat serving as it material-aesthetic form. Ohio clothing retailer Homage produced a t-shirt with the words "Not All Heroes Wear Capes" in honor of Dr. Acton, the proceeds going to help frontline workers (Dakota 2020). When Dr. Acton resigned her position on June 11, DeWine too paid homage to her iconic form: "It's true, not all heroes wear capes. Some of them wear a white coat embossed with the name Dr. Amy Acton" (DeWine 2020). Acton's iconic power had now flowed from the press conferences out the audience and then back to the press conference like a game of iconic telephonenote again that Acton's original statement was "don your capes and keep being a force for good" not "not all heroes wear capes." Still, these videos and products reveal a circulating iconicity around Dr. Acton, available for bricoleurs in the audience and in the government.

While Acton's tribute video was product of the state, in the realm of democratizing kitsch, the components of the press conference writ large became iconicized. For example, the press conference's regularity had taken on material form. FOX 8 News Cleveland profiled Wadsworth, Ohio resident Amy Jenkins who designed a t-shirt that read "Wine with DeWine: It's 2 O'Clock Somewhere" (2020). "Wine with DeWine" can be found on wine glasses—-naturally_and "Snackin' with Acton" on t-shirts and baby's bibs all over the popular e-commerce website Etsy. Indeed, even the Baldwin Wallace poll referenced Wine with DeWine/Snackin' with Acton. In a pair of questions "just for fun," a plurality of respondents $(27.6 \%)$ selected wine as their beverage of choice for watching the $2 \mathrm{pm}$ press conferences, with a close race between chocolate (20.2\%) and fruit and veggies (20.3\%) for the best snack (Baldwin Wallace University 2020, pp. 47-48).

DeWine, Acton, and Marla Berkowitz all have bobblehead dolls designed in their likenesses by the National Bobblehead Hall of Fame and Museum. Both the DeWine and Acton bobbleheads stand behind a podium with the Ohio flag placed against a white circular background-not quite the Seal of Ohio, but close enough! Acton 
wears her trademark white lab coat and DeWine is distinguishable mainly by his blue-rimmed glasses. Berkowitz's bobblehead likeness is as uncanny as her likeness of DeWine: she wears a black blazer and blue button down shirt. She signs "I love you" with both hands. One story covering this new kitschy development was titled, "Love Wine with DeWine? You Can Get a Bobblehead to Drink With" (Brookbank 2020).

Speaking of drinking, News 5 Cleveland's Ian Cross attributes the phrase "Wine with DeWine" to "self-described 'Twitter Bon Vivant' known as McNeil..." or @ Reflog_18 who jokingly developed a Mike DeWine Presser Bingo Game and the \#WineWithDeWine Presser Drinking Game (2020). Both games are actually remarkable examples of aesthetic self-awareness and deconstruction. The bingo game has spaces to fill like "Fran Shares Dessert Recipes," "Marla Interpreting," "Husted Suit," and "Water \& Hand Sanitizer Visible." The drinking game challenges participants to take one drink when they hear "Let's not make this political," to drink once per mention of any of DeWine's grandkids, and once for each reporter's question. Given the frequency of those events during the press conferences, it is safe to say that the game is really not meant to be played seriously. The games are irreverent-quite the opposite of what the presser's cultural performance is aiming for-but they are reliant on the regularity of the press conference's aesthetic and performative components to make sense. Overall, these games and ironic winks encourage play and collective solidarity via direct engagements with the press conferences as icons.

Finally, in a place in between irreverent deconstruction and heroic praise we find an animated short titled "DEWINE \& AMY OPENING THEME." Created by Ohiobased animator Dave Stofka, the short's YouTube description praises DeWine and Action's actions in leading Ohio, "But until now [DeWine's] extremely popular press conferences have never had a theme song" (Stofkacreative 2020). Set to the tune of the theme song of the 1970s sitcom Laverne \& Shirley as well the visuals to its opening sequence, the animated short is loaded with references to the press conferences and Ohio's experience with them.

It opens with an animated DeWine and Acton dressed in their press conference outfits, but taking the place of the sitcom's heroines Laverne and Shirley as they march arm-in-arm in cadence down the street: "One! Two! Three! Four! Five! Six Feet Apart!/Stay Home! Stay Home!/How's about we coordinate it!” DeWine and Acton are shown getting ready in the morning (DeWine drinks from a mug labeled "DeCoffee"), dragging their respective stage props from home to the Statehousefor Acton a large flatscreen TV, for DeWine his podium. Instead of Laverne and Shirley clocking in at their brewery job, DeWine and Acton clock in at the Statehouse. DeWine refuses to shake hands with the guard, saluting him instead. On that beat we get the lyrics, "Offer us your hand, won't shake it/We're gonna see our state pull through!" Husted appears too, twirling through Statehouse rooms like Shirley's dancing boyfriend Carmine in the original intro sequence; and Marla Berkowitz throws toilet paper rolls at Acton and DeWine from her floating on-screen inset, mimicking a scene in the original where Laverne and Shirley throw snowballs at their friends Lenny and Squiggy. The short also features Ohio institutional representations: The Ohio State University mascot Brutus, bottles of Purell being produced 
in a factory (presumably by their Ohio-based maker, GOJO), and DeWine riding a forklift driven by Acton at Battelle Labs in Columbus. The short ends with these solidaristic lyrics, "And we'll do it our way/Yes, our way/See all our state pull through/For me and you" as DeWine and Acton race by on a tandem bike, wearing masks in a dreary, washed out world. Then there is a screen transition, and they are now maskless and color is back.

In sum, the wide range of aesthetic engagements here-from heroic to irreverent-expand the cultural and emotional range of engagement with the press conferences, the heroic by condensation, the irreverent by deconstruction. They rely on the regularity of the press conferences themselves as performances to be meaningful. They all evince a reflexive awareness of what components of the press conferences are meaningful as iconic representations. They remix those components in new ways and add to the layers of significance surrounding the press conferences themselves. In talking about audience fusion, it makes sense to say here that audiences fuse with particular pieces of the press conference. In these ways, public's self-awareness exceeds a strictly discursive one in the Habermasian sense, revealing the public's aesthetic sense of solidarity.

\section{Reception II: populist backlash and irreparable schism}

It is important to note the type and quality of DeWine and Acton's negative reception, again anchored around the press conferences themselves. Starting the week of April 6, anti-lockdown protesters gathered outside the Statehouse, knowing that DeWine's press conferences happened daily at $2 \mathrm{pm}$. On the Statehouse steps and outside the Atrium - the location of the press corps during the briefings - the protesters became bolder and louder as the week wore on. They became audible on the press conference broadcasts, shouting and banging on the Atrium windows. On April 17, President Trump began to send out a series of tweets, ostensibly targeting states led by Democratic governors who had enacted lockdown measures: "LIBERATE MICHIGAN!", "LIBERATE VIRGINIA, and save your 2nd Amendment. It is under siege!", and "LIBERATE MINNESOTA" (Fallow 2020). Though he did not tweet at Ohio or at DeWine, Trump's messages came on the heels of gathering antilockdown protesters around the country and Ohio's protests "were similar in size and makeup as those in other States, not very large but very far right" (Darcy 2020).

An iconic photograph of these protests emerged, taken by Columbus Dispatch photojournalist Joshua A. Bickel (Fig. 1). In the photo, protesters are pressed up against the glass doors of the Statehouse Atrium. In the foreground are two women shouting. They seem to address the viewer directly, but the glass door separates them from the viewer. One was eventually revealed to be Ohio State Senate candidate Melissa Ackison (Jackson 2020). ${ }^{3}$ The other woman, closer to the center of the shot, is holding a small American flag. Behind her are two men with Trump

\footnotetext{
3 Ackison was a candidate in the Republican primary for Ohio's 26th Senate district. She eventually lost the primary to incumbent State Representative Bill Reinke.
} 


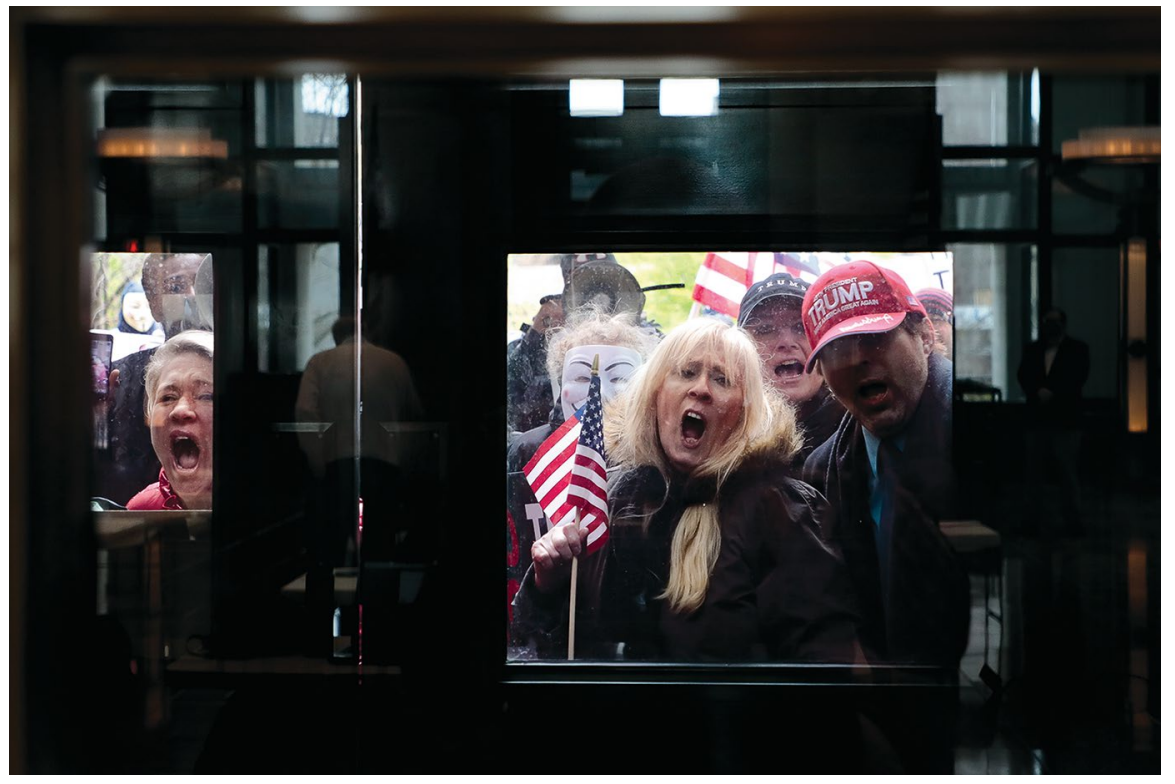

Fig. 1 Protesters outside the Ohio Statehouse Atrium. Joshua A Bickel/The Columbus Dispatch

hats, their faces blurred by the refraction of the window, and behind them a protester wearing a Guy Fawkes mask. There is a faint reflection in the shiny black surface of the doorframe. In it we can see a man inside the Atrium. His back is turned to us and he is looking down as if he is typing on his phone, ignoring or trying to ignore the protesters outside.

The photograph's iconic power comes from the tropes of the civil sphere it evokes. It is like a scene from a zombie movie or a monster movie's village mob. Rational, civil government inside; irrational masses outside. Circulating alongside Alyson McClaran's photograph of a masked healthcare worker standing in front of a protester's van in Denver, and Jeff Kowalski's photo of a man shouting at masked police officers inside the Michigan state house, Bickel's photo offered another powerful condensation of civil and anticivil codes during the lockdown protests for national audiences (Alexander 2006). The Columbus Dispatch's Theodore Decker writes that "As the image went viral, thousands of observers found a pathetic comedy in it. They also rallied around its zombie-movie quality," comparing it to Edgar Wright's 2004 zombie comedy Shaun of the Dead. That reading aside, he continues, "[The protesters'] anger, though, feels narcissistic. It is America's rugged individualism taken to the extreme, the selfishness so in vogue in today's politics... Empathy, sadly, can't be taught" (Decker 2020). 
Or, we might imagine the view of the protesters outside, the faint reflection of the man inside the building like the out-of-touch elite ignoring the people who clamor for freedom from lockdown. Either way, the framing and juxtaposition of subjects in the shot convey the powerful emotional challenge of the protests for the public sphere (see Hariman and Lucaites 2007). In his description of the composition, the photojournalist Bickel remarks, "I remember walking by the door and seeing people up at the door chanting. I thought the framing of the door and was interesting and so I stood there for a brief second kind of composing the picture in my head. I made 7 frames of the scene in about 10 seconds, and then left..." (Everhart 2020). He notes that the photo was one of many he submitted that day and the Dispatch picture editor ultimately attached it to a news story. Asked if he thought the "photo would get so much attention," Bickel responded:

Not at all. I remember thinking the composition was interesting and the people were emotional, but not much beyond that... I should note that this image really isn't my style, meaning I don't cover a lot of breaking news, and I don't think I'm particularly good at it. I like making images that take more patience, more access and more trust between myself and the people I photograph. Trust is really important to me when I'm telling someone's story and I always try to be honest with the images I make. This image is the total opposite of that: it happened quickly, I was in a position where I couldn't talk with these people and I had other things I was responsible for that day. That this image is getting all this attention is not something I expected or set out to achieve (Everhart 2020)

What is so interesting about Bickel's interpretation of his own work is that he lays out a professional and ethical position where the photojournalist and the subject coproduce the photo to create an authentic representation. Here, he signals discomfort with the photo's popularity in part because it does not reflect the deliberate (and deliberative) way he works with his subjects. In that sense, the act of composition seems to reflect the tensions in the image. The "empathy wall" (Hochschild 2016) is a framed glass door. The viewer experiences the emotion of the protesters like a sudden shock, on the inside looking out. Unlike the "deep story" needing to be uncovered, here the break between the sanctuary of the press conferences and the partisanship outside is made visually arresting and right in our faces - an aesthetic "public recognition of irreparable schism" (Turner 1985, p. 198).

The protesters precipitated another set of moves for the press corps and the governing team. On April 17, the governing team moved their broadcast site from the Statehouse to the Ohio Public Safety Department about two miles away. The press corps moved from the Atrium to the Statehouse Crypt in the building's basement. Having to move broadcast and reporting sites because of the protests created performative issues for the press conferences. The audio link between the Statehouse Crypt and the Department of Public Safety was not as consistent nor as clear as the connection between the Atrium and the State Room. Numerous and consistent audio issues resulted in a more disjointed Q-and-A period, with DeWine, Acton, and Husted visibly straining to hear questions from reporters. In terms of the performance 
of ritual and mediatized sanctuary, these audio issues weakened the audience's deep connection with the action on screen.

The protests also put political pressure on Ohio's reopening plans. Supported by far-right members of the Ohio Legislature, the protests had institutional representation (see Staver and Behrens 2020). Though insisting on a phased reopening of the state, DeWine accelerated plans to reopen as the month of April wore on, as Republicans in the House pressured him to move more quickly (see Tobias 2020). In a surprising turnabout after having declared that workers and customers at businesses would be required to wear masks, DeWine announced that he would not mandate that customers wear masks. On April 29, when asked by Ohio Public Radio and Television's Andy Chow if "the input from the anti-mask mandate side weigh[ed] more than the people who were for a mask mandate," DeWine responded "It was clear to me, and should have been clear to me before I made the mandate, that that was just too far and that there's a significant number of Ohioans who are offended by it, [who] thought this was government overreach" (Ohio Channel 2020r, 1:06:50-1:08:37). ${ }^{4}$

On May 19, DeWine lifted the remnants of Dr. Acton's stay-at-home order which was set to expire on May 29. This was on the heels of a weekend where viral videos of packed restaurants and bars raised alarms about voluntary compliance with masks and distancing. When asked by Spectrum News' Molly Martinez if "there are any concerns that we are putting too much faith in people doing the right thing when we've seen example after example of them choosing not to" Lt. Gov. Husted responded, "We have little choice but to trust people. A civil society, quite frankly, depends on public trust. It just does" (Ohio Channel 2020t, 38:40-48, 43:39-41:46). Though wishing not to "violate that trust," Husted and DeWine above effectively abdicated their roles as responsible parties vis-à-vis the social troubles caused by the affliction. Notably absent on May 19 is Dr. Acton, whom DeWine reports as having taken ill.

\section{Dr. Acton's exit}

On May 5, the New York Times posted a video essay analyzing Dr. Acton's performances at the press conferences. Titled "The Leader We Wish We All Had," the creators introduce Dr. Acton to their audience: "You may not have seen her press briefings, but in Ohio they have become a daily ritual, catapulting her from unknown local official to cult icon" (Dosani and Westbrook 2020, 0:36-0:46). They highlight how she empowers audiences by subtle shifts in her pronoun use, how she is brutally honest but eases audiences into bad news, and how she demonstrates her own vulnerability. "Dr. Acton inspired millions of Ohioans to stay home-not by ordering them, but by inspiring them" (Dosani and Westbrook 2020, 6:03-6:05). The

\footnotetext{
${ }^{4}$ DeWine would announce a statewide mask mandate on July 22, nearly two months after this first attempt and months after refusing to give an order. Coincidentally, the mandate came a day after lockdown opponent and Speaker of the Ohio House Larry Householder was arrested by the FBI for racketeering.
} 
implication here is that Acton is the honest, empathetic leader that Pres. Trump is not. And, in the context of an increasing partisan coloring on public health interventions around the country, Dr. Acton's leadership here is understood in fully cultural terms - iconic, ritual, performative, narrative, and emotional. Remarkably too, the press briefings are described in the video as Dr. Acton's, not DeWine's.

As much as the video affirmed what many Ohioans had been seeing and feeling about Dr. Acton for the past two months, the first week of May would see increasingly emboldened protesters target Acton and members of the press corps. On May 1, NBC4's Adrienne Robbins was aggressively confronted by a protester outside the Statehouse. Starting on May 2, protesters began to gather outside of Dr. Acton's house in the Columbus, Ohio suburb of Bexley. Both of these incidents drew a rebuke from DeWine on May 4:

I am fair game. But I want to talk for a moment what's not fair game. It's not fair game to disrespect the news media, to be obnoxious to the new media... you should come after me... Let me say what else is not fair game... the members of my cabinet work exceedingly, exceedingly hard, but I set the policy. When you don't like the policy, you can demonstrate against me, that's fair game. But to bother the family of Dr. Acton, I don't think that's fair game. I don't think that right.... (Ohio Channel 2020s, 10:22-10:35)

At this point, the protests "seemed hell-bent on destroying the autonomy of civil sphere institutions along the way" (Alexander 2019, p. 8). DeWine's response was surprisingly confrontational, but it amounted to a last-ditch effort to use the symbolic power of his office to insulate the press and Acton from partisan pressure.

Despite DeWine's vocal defense, Acton would continue to be a target. Lawsuits from owners of day cares, amusement parks, music festivals, and bridal stores alleged her health orders were excessive. Legislators sought to pass bills that would curtail hers and the governor's power to issue those orders (Borchardt 2020). Back in April, Republican State Senator Andrew Brenner and his wife Sarah Marie were "fiercely rebuked" by Republican leadership and the Jewish community for comparing Dr. Acton's orders to living in Nazi Germany- "Sen. Brenner's wife claimed she did not know Acton was Jewish" (nbc4i.com 2020). State Representative Nino Vitale evoked anti-Semitic conspiracy theories when he called Dr. Acton a "Globalist Health Director" (10TV Web Staff 2020). And Representative Paul Zeltwanger called for her resignation as her disease model predictions never came to pass (Behrens 2020).

Through May and into June, Dr. Acton would become a less prominent actor during the press conferences. Using the timestamps on the Ohio Channel recordings, we can get an estimate of the time officially dedicated to Dr. Acton's presentations, not including the press' question-and-answer period. In the first two months of the press conferences, Dr. Acton's main presentation lasted an average of ten minutes, fifty-one seconds in March and nine minutes, fifty-six seconds in April. She gave her longest presentation-twenty-minutes and fortyseconds-on March 13. In contrast, in May and June Dr. Acton's average presentation time noticeably declined: a seven-minute average in May and a six minute, 
Table 1 Presentation time for Dr. Amy Acton, March 3-June 11, 2020

\begin{tabular}{lllll}
\hline & Press conferences attended & $\begin{array}{l}\text { Average time } \\
\text { for presentation } \\
\text { (mm:ss) }\end{array}$ & $\begin{array}{l}\text { Longest presentation } \\
(\mathrm{mm}: \mathrm{ss})\end{array}$ & $\begin{array}{l}\text { Shortest } \\
\text { presentation } \\
\text { (mm:ss) }\end{array}$ \\
\hline March & 24 out of $25(96 \%)$ & $10: 51$ & $20: 40$ (March 13) & $3: 58$ (March 3) \\
April & 20 out of $23(87 \%)$ & $9: 56$ & $14: 30$ (April 5) & $5: 55$ (April 29) \\
May & 10 out of $12(83 \%)$ & $7: 00$ & $11: 44$ (May 4) & $2: 10$ (May 21) \\
June & 3 out of $4(75 \%)$ & $6: 44$ & $10: 33$ (June 2) & $6: 39$ (June 11) \\
Overall & 57 out of $64(89 \%)$ & $8: 37$ & $20: 40$ (March 13) & $2: 10$ (May 21) \\
\hline
\end{tabular}

Source Timestamps on Ohio Channel recordings of Gov. DeWine's Coronavirus Press Conferences, hand timing for March 3. Note: not a measure of speaking time

forty-four second average in June. She also gave her shortest presentation of two minutes and ten seconds on May 21 (Table 1).

Indeed, the May 21 press conference is exemplary in showing how the ritualized and sanctuary features of earlier weeks had broken down. DeWine announced a series of initiatives to address the social determinates of health, especially as they pertain to outreach for testing for Coronavirus in minority communities. The guest via remote broadcast is Cincinnati Vice-Mayor Christopher Smitherman and he and DeWine talk at length about the initiative. Practically left out is Dr. Acton, who spends her two minutes simply reading the data from the state's Coronavirus website. She gives no additional commentary or explanation, no inspiring pep talk. She asks Vice-Mayor Smitherman a couple of very deferential questions after he and DeWine are done speaking. Dr. Acton may have been on stage, but she was no longer a lead character.

There is also an exemplary exchange between DeWine and Jack Windsor, a self-styled independent investigative reporter associated with TV station WMFDMansfield in North-Central Ohio. In July 2020, the New York Times profiled Windsor alongside Coronavirus contrarian Alex Berenson. It revealed that Windsor, a wedding venue operator incensed by lockdown business restrictions, "had gotten a small, independent television station to give him a press pass..." (Smith 2020). Now part of the press corps, Windsor has consistently asked long questions with a rightwing slant, critical of the extent of infection in Ohio and the state government's efforts to manage the spread. If viewers could rely on some respite from partisanship in previous months, Windsor's presence signaled the opposite: explicit partisanship breaking the performance of sanctuary. In the words of Ohio Capital Journal's Tyler Buchanan, "Nearly every question asked by Ohio's press corps at the daily COVID19 news conferences are solid/helpful. There is a specific, constant exception to that just about every single day" (2020):

Jack Windsor, WMFD-TV Mansfield. Governor, I'm the last question and my question is for you, and it's going to be a very sensitive question and I'm going to do my best to be intentional so that it's not misrepresented. Today it sounds like we're pivoting from COVID to larger social issues like housing, education, and transportation. I know in past pressers we've learned 
about Dr. Paul Farmer and Partners in Health working with us on contact tracing. Looking at the Partners in Health website, contact tracing seems to be part of a larger social agenda for Partners in Health. The site states a vision to rectify quote, "structural violence of capitalism," which this organization sees as the root cause of such things such as racism, gender inequality, xenophobia, and homophobia. Now, I'm not questioning the injustice of those things, Governor, so let me be very clear about that. What my question is, can you tell us why you chose to partner with an organization that demonizes capitalism and seems to be rooted in Liberation Theology based on Marxist ideals? (Ohio Channel 2020u, 1:18:26-1:19:29)

Just as Windsor finishes speaking, DeWine cracks a bemused smile as if to signal how audacious he thinks the question is - and that he thinks he's got a good answer. "Well, I've never always agreed with Paul Farmer," DeWine begins. He follows with staccato emphasis, "but he and the organization have had an ability to deliver health services" (Ohio Channel 2020u, 1:19:31-1:19:43). He then reveals that he and his wife Fran have gone down to see Farmer's work in Haiti twenty times. Partners in Health staff will not be conducting the contact tracing, but Ohioans will: "You don't have to accept the ideology of Paul or anybody else, but what I'm interested in is getting things done. And they're not the ones doing it on the ground" (Ohio Channel 2020u, 1:20:00-1:20:13). While on its face, we might read this exchange as a dynamic and interrogative one in a Habermasian vein, Windsor and DeWine play out a different kind of performance here-one of one-upmanship, their questions and answers like played like chess pieces rather than as refinement of argument. Testy exchanges like this one would elevate Windsor's star in a charismatic way, he a plucky upstart whose "confidence is larger than their present station" (Joosse 2017, p. 934). Windsor would eventually gain his own Facebook fan page, testify before the Ohio House in favor a bill for "accurate reporting" of COVID statistics in May, and be a guest speaker at an anti-mask rally in July.

On June 11, when Dr. Acton announced her resignation as Director of Health to take on a behind-the-scenes role as an advisor to DeWine, she did not reference partisan pressures or lawsuits as her reason for stepping down. She was as effusive and generous as ever, thanking her staff at the Department of Health, local health departments, and others referring to herself as just the tip of an iceberg (Ohio Channel 2020v, 25:00-29:05). In a final reference to the sacrifice and hard work necessary for affliction to be relieved, Acton said, "I really want to say most of all to Ohioans: Ohioans you have saved lives. You've done this" (Ohio Channel 2020v, 20:15-20:19). With partisan pressure unrelenting in the past two months, audiences could reasonably assume politics was at least part of the cause, perhaps among many other unseen ones: "There wasn't one moment that pushed Acton to resign. No politician or angry protester pushed her out..." (Balmert and Borchardt 2020). Like many other health officials around the country who had resigned their posts during the pandemic, Acton held long hours and likely had experienced burnout (Balmert and Borchardt 2020). Still, with Acton's resignation, a major actor in the performance of ritual was now gone. Audiences could no longer expect the components of 
the ritual to be performed as they were in March, and as such, could no longer count on a sanctuary from partisanship and the pandemic.

\section{Conclusion}

This paper made the case for understanding Ohio's Coronavirus press conferences as mediatized sanctuaries, built from the basic ritual structure of a ritual of affliction. It suggests that DeWine, Acton, and Husted played complementary roles in that ritual during the press conference where they divine the pattern of Coronavirus trouble, guide sacrifice to appease it, and root collective response to it in institutionalized leadership. They did this by having Ohioans recall basic cultural commitments like family and children, and maintaining as much as possible a social space where political considerations and partisan epistemologies are bracketed out. This ritual structure explains positive feelings of comfort and stability. This paper also argued that the range of cultural and emotional engagements with the press conference are not limited to affirmative deference. By looking at iconic representations of the press conferences, we can see their wide use from heroic reverence to ironic irreverence. The regularity of the press conferences and their standout props, characters, and settings allow them to anchor a wider universe of meanings. Finally, this paper argued that anti-lockdown pressures fundamentally altered the sanctuary quality of the press conferences, concluding with Dr. Acton's resignation. Ultimately, responsible parties could not heal the irreparable schism of partisanship at the end of the day.

Three points are worth considering here. The first is a Weberian one: Did we witness the tensions inherent in the routinization of charisma? DeWine's mild-mannered sensibilities and long political career would have otherwise predisposed him to national obscurity in this mediatized and dramatic-charismatic political context. Instead, his star rose quickly among national and international audiences. In the broader context of national and international partisan epistemology, it was DeWine's willingness to act against President Trump that mattered the most. That, and he relied on Dr. Action's counsel to guide his early policy decisions. To the extent that DeWine led via charisma, it was a "conservative charisma" that "conformed to orthodox norms of virtue" (Smith 2000, p. 6) to which Trump did not conform. Then, it was the instrumental motivations of party politics that led to a denaturing of DeWine's charismatic authority.

Certainly, decisive action and thoughtful policy strongly contrasted to the federal government's inaction could explain DeWine's rise in symbolic power. But what this paper reveals is that the ritualized sanctuary that emerged from DeWine's press conferences provided the cultural structure that rooted the governor's action in a horizon of meaning. Indeed, if charisma requires a reframing of opponents as antagonists in salvation narratives (Smith 2000), neither DeWine-nor Acton-were willing to deviate strongly from the sanctuary script established in March and engage anti-lockdown protesters and legislators as charismatic foils (see Joosse 2017). Contrast this to Michigan's Gretchen Whitmer and New York's Andrew Cuomo who rode waves of partisan tension by openly challenging Trump and protesters in their states. But DeWine, simply put, was never a charismatic leader to begin with. What 
national audiences saw was partisan tension driving the show, but not the content or structure of the ritual of affliction that attempted to keep that tension at bay. Again, at the end of the day the contingent qualities of the ritual performance-its physical setting, its cast, its subjunctive script-were undermined by the protests, and with that, DeWine's authority, Acton's job, and ultimately Ohio's mitigation efforts to slow the spread of Coronavirus.

Second, this paper has attempted to show that the press conferences exceeded a Habermasian rational-critical speech situation and that the press conferences were experienced by a sufficiently self-aware audience, not ideological dopes. The anchor concept here is the contingency of performance. In several unintended ways the components of the ritual came together and gathered far more cultural steam than DeWine, Acton, or anyone else could have predicted in early March. When DeWine appointed Acton as Director of Health in February 2019, neither could have predicted they would be leading during a global pandemic. The press corps' repositioning for the sake of social distancing led to a change in the mise-en-scène that connected audiences to DeWine, Acton, and Husted in a more intimate way.

Similarly, reception had contingent features, too. It is surprising that in a highly polarized and gerrymandered state like Ohio, a vast majority of Republicans and Democrats supported DeWine, Acton, and their interventions. The aesthetic engagement with the press conferences ranged from laud to irreverence, from slickly produced videos to self-made t-shirts with catchphrases, all inspired by the iconic quality of the press conferences themselves. That anti-lockdown protesters would go after a Republican governor who has nominally strong relations with Pres. Trump was also a surprise. But in this framework, that the protests targeted the press, Acton, and the other components of the ritual performance is not surprising because the press conferences had a structuring effect on meaning, even for those opposed to them. At the end of the day, we miss the importance of visual aesthetics, dramatics, and poetics of these press conferences by dismissing them as surface features lacking in depth or focusing on just rational discourse. One upshot is that citizen-audiences in Ohio have a new anchor idea of what good government looks like because of the press conferences at their height-this is no small expectation for current and future leaders to meet.

Finally, this paper uses Turner's concept of ritual of affliction to explain why the press conferences provided a sense of sanctuary in mediatized form. Though the sanctuary of the press conferences was a contingent achievement and ultimately an impermanent one, sanctuary came at the right time for Ohioans who were thrust into unknown territory with their jobs, their families, their schooling, and their physical and mental health. Back on March 13, Dr. Acton noted the importance of conducting a "hotwash": an assessment of lessons learned as a result of the interventions made. What I hope those agencies, stakeholders, and leaders might include in their assessment are the cultural structures that anchored their actions in a horizon of meaning. In Ohio at least, the press conferences exceeded their function as a communication strategy: they were the cultural centerpiece that allowed Ohioans to experience the pandemic interventions together. And, while we might say DeWine, Acton, Husted, Marla Berkowitz, Lena Smith, 
Jim Otte, Laura Bischoff, and other new household names and faces were good communicators individually, their performances in the ritual structure mattered. Together they helped security and regularity to become emotional and cultural resources in an otherwise chaotic time. At the end of the day, all these humanistic elements might not fit neatly in a disease model, but I submit they may be what makes or breaks intervention strategies for large populations. One hopes that we never have to experience a pandemic again in our lifetimes, but if another one does come, we need to remember how Ohio's ritual of affliction came to be and how it came to an end.

Acknowledgements Many thanks to the reviewers and editors of AJCS. I am very grateful to Andrew Welsh-Huggins, Joshua A. Bickel, and to the students of SOCY252 - "Cultural Foundations of Politics" whose candor and work motivated me to write this paper.

\section{References}

Alexander, J.C. 1985. Review essay: Habermas' new critical theory: Its promise and problems. American Journal of Sociology 91 (2): 400-424.

Alexander, J.C. 2006. The civil sphere. New York: Oxford University Press.

Alexander, J.C. 2008. Iconic consciousness: The material feeling of meaning. Environment and Planning D: Society and Space 26 (1): 782-794.

Alexander, J.C. 2010. The performance of politics. Obama's victory and the democratic struggle for power. New York: Oxford University Press.

Alexander, J.C. 2011. Performance and power. Cambridge: Polity Press.

Alexander, J.C. 2014. The fate the of the dramatic in modern society: Social theory and the Avant-garde. Theory, Culture, and Society 31 (1): 3-24.

Alexander, J.C. 2019. Frontlash/backlash: The crisis of solidarity and the threat to civil institutions. Contemporary Sociology 48 (1): 5-11.

Alexander, J.C., E.B. Breese, and M. Luengo (eds.). 2016. The crisis of journalism reconsidered. New York: Cambridge University Press.

Alexander, J.C., and N.B. Jaworski. 2014. Obama power. Cambridge: Polity Press.

Baldwin Wallace University. 2020. The Baldwin Wallace University Ohio poll. https://www.bw.edu/ Assets/community-research-institute/04-2020_ohio_poll\%20release.pdf. Accessed 4 Aug 2020.

Balmert, J., and J. Borchardt. 2020. First came the pandemic, then came the politics: Why Amy Acton quit. Cincinnati Enquirer, 13 June. https:/www.cincinnati.com/story/news/2020/06/12/why-ohiohealth-department-director-amy-acton-quit/3174400001/. Accessed 31 Aug 2020.

BBC. 2020. The US governor who saw it coming early. 1 April. https://www.bbc.com/news/world-uscanada-52113186\#. Accessed 27 June 2020.

Behrens, C. 2020. Mason Rep. calls for resignation and replacement of Director Amy Acton. Cincinnati Enquirer, 28 May. https://www.cincinnati.com/story/news/2020/05/28/mason-rep-calls-resignatio n-and-replacement-director-amy-acton/5274787002/. Accessed 31 Aug 2020.

Binder, W. 2017. The drama of politics: Jeffrey Alexander's liberal sociology of political performances. Thesis Eleven 142 (1): 112-129.

Birnbaum, N. 1955. Monarchs and sociologists: A reply to professors Shils and Young. The Sociological Review 3 (1): 5-23.

Bischoff, L. 2020. New poll: Trump, Biden tied in Ohio; DeWine's approval rating sky-high. Dayton Daily News, 25 June. https://www.daytondailynews.com/news/local/new-poll-trump-biden-tiedohio-dewine-approval-rating-sky-high/QG0mWJFjYLi2QiZvZPHXfI/. Accessed 3 July 2020.

Bogard, C.J., and I. Sheinheit. 2016. Authenticity and carrier agents: The social construction of political gaffes. Sociological Forum 31 (4): 970-993.

Borchardt, J. 2020. Lawmaker: Bill would kill coronavirus orders; curb power of health director, governor. Cincinnati Enquirer 2 May. https:/www.cincinnati.com/story/news/2020/05/02/ohio-john-becke 
r-repeal-coronavirus-orders-curb-power-health-director-amy-acton-mike-dewine/3071650001/. Accessed 31 Aug 2020.

Brookbank, S. 2020. Love wine with DeWine? You can get a bobblehead to drink with. Columbus Dispatch, 24 April. https://www.dispatch.com/news/20200424/love-wine-with-dewine-you-can-getbobblehead-to-drink-with. Accessed 1 July 2020.

Buchanan, T. 2020. Tweet 5 May, 2:43pm Twitter/@tylerjoelb.

Clement, S. and Balz, D. 2020. Many governors win bipartisan support for handling of pandemic, but some Republicans face blowback over reopening efforts. Washington Post 12 May. https://www. washingtonpost.com/politics/many-governors-win-bipartisan-support-for-handling-of-pandemicbut-some-republicans-face-blowback-over-reopening-efforts/2020/05/11/8e98500e-93d2-11ea-9f5e56d8239bf9ad_story.html. Accessed 30 Aug 2020.

Coffey, D.J., J.C. Green, and D.B. Cohen. 2011. Buckeye battleground: Ohio, campaigns, and election in the twenty-first century. Akron: University of Akron Press.

Cottle, S. 2006. Mediatized rituals: Beyond manufacturing consent. Media, Culture and Society 28 (3): $411-432$.

Couldry, N., and A. Hepp. 2013. Conceptualization mediatization: Contexts, traditions, arguments. Communication Theory 23 (3): 191-202.

Craig, G. 2016. Performing politics: Media interviews, debates, and press conferences. Cambridge: Polity Press.

Cross, I. 2020. The one thing Ohioans do together during the coronavirus: daily DeWine press conferences. News 5 Cleveland, 26 March. https://www.news5cleveland.com/news/continuing-coverage/coronaviru s/the-one-thing-ohioans-do-together-during-coronavirus-the-daily-dewine-press-conference. Accessed 27 June 2020.

Dakota, M. 2020. 'Not all heroes wear capes': Ohio t-shirt company pays homage to ODH, health care workers statewide. Cleveland19.com, July 2. https://www.cleveland19.com/2020/03/18/not-all-heroes-wearcapes-ohio-t-shirt-company-pays-homage-odh-healthcare-workers-statewide/. Accessed 27 June 2020.

Darcy, J. 2020. Trump 'liberate' tweets enable protesters: Darcy cartoon. Cleveland.com, 21 April. https ://www.cleveland.com/darcy/2020/04/trump-liberate-tweets-enable-protesters-darcy-cartoon.html. Accessed 31 Aug 2020.

Dayan, D., and E. Katz. 1992. Media events. Cambridge: Harvard University Press.

Decker, T. 2020. Thomas Decker: Viral Statehouse photo puts face on coronavirus debate. Columbus Dispatch, 17 April. https://www.dispatch.com/opinion/20200417/theodore-decker-viral-statehouse-photo -puts-face-on-coronavirus-debate. Accessed 7 June 2020.

DeWine, M. 2020. Tweet June 11, 2:29pm. Twitter.com/@GovMikeDeWine.

Dosani, S., and A. Westbrook. 2020. The leader we wish we all had. New York Times, 5 May. https://www. nytimes.com/2020/05/05/opinion/coronavirus-ohio-amy-acton.html. Accessed 27 June 2020.

Exner, R. 2020a. Ohio loses 39,700 jobs, unemployment rate increases to 5.5\% in March report; full hit from coronavirus not reflected. Cleveland.com, 17 April. https://www.cleveland.com/datacentral/2020/04/ ohio-loses-39700-jobs-unemployment-rate-increases-to-55-in-march-full-hit-from-coronavirus-notreflected-in-report.html. Accessed 1 July 2020.

Exner, R. 2020b. Ohio's unemployment rate nearly triples to $16.8 \%$ in April. Cleveland.com, 22 May. https ://www.cleveland.com/datacentral/2020/05/ohios-unemployment-nearly-triples-to-164-in-april.html. Accessed 1 July 2020.

Everhart, M. 2020. You've seen the photo of the Ohio protesters. Here's the story behind it. Columbus Dispatch, 16 April. https://www.dispatch.com/news/20200416/yoursquove-seen-photo-of-ohioprotesters-herersquos-story-behind-it. Accessed 7 June 2020.

Fallow, J. 2020. 2020 time capsule \#15: Liberate. The Atlantic, 18 April. https://www.theatlantic.com/notes /2020/04/2020-time-capsule-15-liberate/610252/. Accessed 31 Aug 2020.

Fishbein, R. 2020. Help, I think I'm in love with Andrew Cuomo. Jezebel, 19 March. https://jezebel.com/ help-i-think-im-in-love-with-andrew-cuomo-1842396411. Accessed 29 June.

FOX 8 News Cleveland. 2020. Ohioans turn governor's daily coronavirus press conference into "Wine with DeWine." 2 April. https://www.youtube.com/watch?v=HJeGTF-EIyA. Accessed 21 June 2020.

Habermas, J. 1996. Between facts and norms: Contributions to a discourse theory of law and democracy (trans: William Rehg). Cambridge: The MIT Press.

Hariman, R., and J.L. Lucaites. 2007. No caption needed: Photographs, public culture, and liberal democracy. Chicago: University of Chicago Press.

Hendriks, H., and B. van Doorn. 2015. Ohio: The battlegrounds of battlegrounds, In: D.A. Schultz, R. Jacob (eds.) Presidential swing states: Why only ten matter. Washington, D.C.: Lexington Books, pp. 65-82. 
Hochschild, A.R. 2016. Strangers in the own land: Anger and mourning on the American right. New York: The New Press.

Jackson, T. 2020. Ackison goes viral in photo. Sandusky Register, 26 April. https://sanduskyregister.com/ news/243587/ackison-goes-viral-in-photo/. Accessed 24 Aug 2020.

Jacobs, R.N. 1999. Race, media, and civil society. International Sociology 14 (3): 355-372.

Joosse, P. 2017. Countering Trump: Toward a theory of charismatic counter-roles. Social Forces 97 (2): 921-944.

Kidder, J.L. 2018. Civil and uncivl places: The moral geography of College Republicans. American Journal of Cultural Sociology 6 (1): 161-188.

Kreiss, D. 2019. The fragmenting of the civil sphere: How partisan identity shapes the moral evaluation of candidate epistemology. In Politics of meaning/Meaning of Politics, ed. J.L. Mast and J.C. Alexander, 223-241. Cham: Meaning of Politics/Politics of Meaning.

Mann, M. 1986. The sources of social power, vol. 1: A history of power from the beginning to 1760. New York: Cambridge University Press.

Martin, J., and A. Burns. 2020. Once political b-listers, governor lead nation's Coronavirus response. New York Times, 17 March. https://www.nytimes.com/2020/03/17/us/politics/governors-coronavirus-trump .html. Accessed 10 June 2020.

Mast, J.L. 2013. The performative presidency. Cambridge: Cambridge University Press.

Mast, J.L. 2019. Legitimacy troubles and the performance of power in the 2016 US presidential election. In Politics of meaning/Meaning of politics, ed. J.L. Mast and J.C. Alexander, 243-266. Cham, Switzerland: Palgrave Macmillan.

Mehta, D. 2020. Most Americans like how their governor is handling the Coronavirus outbreak. FiveThirtyEight 10 April. https://www.washingtonpost.com/politics/many-governors-win-bipar tisan-support-for-handling-of-pandemic-but-some-republicans-face-blowback-over-reopening-effor ts/2020/05/11/8e98500e-93d2-11ea-9f5e-56d8239bf9ad_story.html. Accessed 30 Aug 2020.

Norton, M. 2019. When voters are voting, what are they doing? Symbolic selection and the 2016 presidential election. In Politics of meaning/Meaning of politics, ed. J.L. Mast and J.C. Alexander, 35-52. Cham, Switzerland: Palgrave MacMillan.

Ohio Channel. 2020a. Dr. Acton inspires heroes. https://www.youtube.com/watch?v=rHumcqALhiA. Accessed 23 June 2020.

Ohio Channel. 2020b. Governor Mike DeWine-3-9-2020 COVID-19 update. https://ohiochannel.org/ video/governor-mike-dewine-3-9-2020-covid-19-update. Accessed 20 June 2020.

Ohio Channel. 2020c. Governor Mike DeWine-3-10-2020 COVID-19 update. https://ohiochannel.org/ video/governor-mike-dewine-3-10-2020-covid-19-update. Accessed 20 June 2020.

Ohio Channel. 2020d. Governor Mike DeWine-3-11-2020 - COVID-19 update. https://ohiochannel.org/ video/governor-mike-dewine-3-11-2020-covid-19-update. Accessed 18 June 2020.

Ohio Channel. 2020e. Governor Mike DeWine-3-12-2020 - COVID-19 update. https://ohiochannel.org/ video/governor-mike-dewine-3-12-2020-covid-19-update. Accessed 18 June 2020.

Ohio Channel. 2020f. Governor Mike DeWine-3-24-2020 - COVID-19 update. https://ohiochannel.org/ video/governor-mike-dewine-3-24-2020-covid-19-update. Accessed 20 June 2020.

Ohio Channel. 2020g. Governor Mike DeWine-3-25-2020 COVID-19 update. https://ohiochannel.org/ video/governor-mike-dewine-3-25-2020-covid-19-update. Accessed 20 June 2020.

Ohio Channel. 2020h. Governor Mike DeWine-3-26-2020 COVID-19 update. https://ohiochannel.org/ video/governor-mike-dewine-3-26-2020-covid-19-update. Accessed 20 June 2020.

Ohio Channel. 2020i. Governor Mike DeWine-3-29-2020 COVID-19 update. https://ohiochannel.org/video /governor-mike-dewine-3-29-2020-covid-19-update. Accessed 21 June 2020.

Ohio Channel. 2020j. Governor Mike DeWine-3-31-2020 COVID-19 update. https://ohiochannel.org/video /governor-mike-dewine-3-31-2020-covid-19-update. Accessed 22 June 2020.

Ohio Channel. 2020k. Governor Mike DeWine-4-1-2020 COVID-19 update. https://ohiochannel.org/video/ governor-mike-dewine-4-1-2020-covid-19-update. Accessed 23 June 2020.

Ohio Channel. 20201. Governor Mike DeWine-4-2-2020 COVID-19 update. https://ohiochannel.org/video/ governor-mike-dewine-4-2-2020-covid-19-update. Accessed 24 June 2020.

Ohio Channel. 2020m. Governor Mike DeWine-4-3-2020 COVID-19 update. https://ohiochannel.org/video /governor-mike-dewine-4-3-2020-covid-19-update. Accessed 24 June 2020.

Ohio Channel. 2020n. Governor Mike DeWine-4-4-2020 COVID-19 update. https://ohiochannel.org/video/ governor-mike-dewine-4-4-2020-covid-19-update. Accessed 25 June 2020. 
Ohio Channel. 2020o. Governor Mike DeWine-4-6-2020 COVID-19 update. https://ohiochannel.org/video/ governor-mike-dewine-4-6-2020-covid-19-update. Accessed 26 June 2020.

Ohio Channel. 2020p. Governor Mike DeWine-4-8-2020 COVID-19 update. https://ohiochannel.org/video/ governor-mike-dewine-4-8-2020-covid-19-update. Accessed 27 June 2020.

Ohio Channel. 2020q. Governor Mike DeWine-4-10-2020 COVID-19 update. https://ohiochannel.org/ video/governor-mike-dewine-4-10-2020-covid-19-update. Accessed 27 June 2020.

Ohio Channel. 2020r. Governor Mike DeWine-4-29-2020 - COVID-19 update. https://ohiochannel.org/ video/governor-mike-dewine-4-29-2020-covid-19-update. Accessed 30 August 2020.

Ohio Channel. 2020s. Governor Mike DeWine-5-4-2020 - COVID-19 update. https://ohiochannel.org/ video/governor-mike-dewine-5-4-2020-covid-19-update. Accessed 30 August 2020.

Ohio Channel. 2020t. Governor Mike DeWine-5-19-2020 - COVID-19 update. https://ohiochannel.org/ video/governor-mike-dewine-5-19-2020-covid-19-update. Accessed 30 August 2020.

Ohio Channel. 2020u. Governor Mike DeWine-5-21-2020 - COVID-19 update. https://ohiochannel.org/ video/governor-mike-dewine-5-21-2020-covid-19-update. Accessed 24 June 2020.

Ohio Channel. 2020v. Governor Mike DeWine-6-11-2020 - COVID-19 update. https://ohiochannel.org/ video/governor-mike-dewine-6-11-2020-covid-19-update. Accessed 30 August 2020.

Ryfe, D.M. 1999. Franklin Roosevelt and the fireside chats. Journal of Communication 49 (4): 80-103.

Shils, E., and M. Young. 1953. The meaning of the coronation. The Sociological Review 1 (2): 63-81.

Smith, P. 2000. Culture and charisma: Outline of a theory. Acta Sociologica 43 (2): 101-111.

Smith, B. 2020. An ex-Times reporter. An Ohio wedding provider. Covid contrarians go viral. New York Times, 19 July. https://www.nytimes.com/2020/07/19/business/media/coronavirus-contrarians-lockd owns-masks.html. Accessed 24 Aug 2020.

Sopel, J. 2020. Coronavirus: Trump berates media at jaw-dropping briefing. BBC News, 14 April. https:// www.bbc.com/news/world-us-canada-52276004. Accessed 29 August 2020.

Staver, A., and C. Behrens. 2020. GOP lawmakers, protesters call on DeWine to being reopening Ohio. Columbus Dispatch, 12 April. https:/www.dispatch.com/news/20200413/gop-lawmakers-protesters -call-on-dewine-to-begin-re-opening-ohio. Accessed 31 Aug 2020.

Stofkacreative. 2020. DEWINE \& AMY OPENING THEME. https://www.youtube.com/watch?v=awc0b 1NamSo. Accessed 3 June 2020.

Tavory, I., and S. Timmermans. 2014. Abductive analysis: Theorizing qualitative research. Chicago: University of Chicago Press.

Tobias, A. 2020. Republican state lawmakers sign on to plan calling for immediate and full re-opening of Ohio businesses. Cleveland.com 27 April. https://www.cleveland.com/open/2020/04/republican-state -lawmakers-sign-on-to-plan-calling-for-immediate-and-full-re-opening-of-ohio-businesses.html. Accessed 29 Aug 2020.

Turner, V. 1981. The drums of affliction. A study of religious processes among the Ndembu of Zambia. Ithaca: Cornell University Press.

Turner, V. 1985. On the edge of the bush. Anthropology as experience. Tucson: University of Arizona Press.

Wehrmann, J., and J. Siegel. 2019. The bad. Ohio gerrymandering is a among the nation's worst. The good? It should get better. Columbus Dispatch, 21 March. https://www.dispatch.com/news/20190321/badohio-gerrymandering-is-among-nations-worst-good-it-should-get-better. Accessed 30 June 2020.

Witte, G., and K. Zezima. 2020. Ohio Gov. Mike DeWine's coronavirus response has become a national guide to the crisis. Washington Post, 16 March. https://www.washingtonpost.com/national/coronaviru s-ohio-dewine-outbreak/2020/03/16/9bde6b1e-67b2-11ea-9923-57073adce27c_story.html. Accessed 29 June 2020 .

Publisher's Note Springer Nature remains neutral with regard to jurisdictional claims in published maps and institutional affiliations.

Celso M. Villegas is Associate Professor of Sociology at Kenyon College, Gambier, OH USA. He has published on civil sphere theory and middle-class formation, as well as middle-class protests and populism in the Philippines, Venezuela, and Ecuador. 